\title{
EKSPLORASI KEBERADAAN GENOTIPE POTENSIAL PADI LOKAL DI WILAYAH BARAT- SELATAN ACEH
}

\author{
Wira Hadianto $^{1 *}$, Sumeinika Fitria Lizmah ${ }^{1}$, Muhammad Jalil ${ }^{1}$ \\ ${ }^{1}$ Program Studi Agroteknologi, Fakultas Pertanian, Universitas Teuku Umar, \\ Jl. Alue Peunyareng, Kec. Meureubo Kab. Aceh Barat, meulaboh \\ *email korespondensi: wira.hadianto@utu.ac.id
}

\begin{abstract}
The South-West Region of Aceh is one of the regions in the province of Aceh that is very rich in local rice diversity that needs to be identified and utilized as a source of genes in assembling new superior varieties to support food security and sustainable agriculture. This study aims to determine the presence of potential local rice genotypes in the South-West Region of Aceh. This research was carried out in the South-West region of Aceh for potential local rice exploration. The survey results in the Aceh Barat-Selatan region have several potential genotypes of local rice in districts in the South-West Aceh region that are still cultivated by farmers in the south, while potential local gonotypes of rice in the South-West Aceh region, namely Aceh Jaya district: , Jantoeng, Sikleng, Ramos, Sijane, Dewi and Leukat Jeuram, West Aceh districts: Itam Tangke Lango, Head of Gidan Kinco, Lekat jero Lango, Sirendeh Semantuk Wayla and Bo Rayek Semantok Wayla. Nagan Raya Regency: Siputeh, Manyam U and Lekat Tuleng, Southwest Aceh Regency: Sigupai. South Aceh Regency: Sitandun, Silian. Simeulue Regency: Sambai and Pade Sialek.
\end{abstract}

Keywords: Exploration, Local of Rice

\section{PENDAHULUAN}

Padi merupakan komoditas penting dalam kehidupan manusia karena sumber utama makanan pokok di seluruh dunia. Sekitar $80 \%$ dari produksi padi dunia berasal dari budidaya padi di Asia (Oryza sativa L.) yang diyakini berasal dari Asia Selatan dan Asia Tenggara. Seleksi melalui alam dan domestifikasi manusia selama ribuan tahun telah menghasilkan keragaman genetik padi sebagaimana tercermin dalam lebih dari 140.000 varietas lokal (landrace) dan varietas padi yang ada saat ini. Jumlah variabilitas genetik spesies sangat penting untuk kelangsungan hidup dan adaptasi di lingkungan yang berbeda.

Wilayah Barat-Selatan Aceh merupakan salah satu wilayah di provinsi Aceh yang sangat kaya akan keanekaragaman padi lokal yang perlu diidentifikasi dan dimanfaatkan sebagai sumber gen dalam perakitan varietas unggul baru untuk mendukung ketahanan pangan dan pertanian berkalanjutan. Identifikasi sifat-sifat penting yang terdapat pada padi lokal perlu terus dilakukan agar dapat diketahui potensinya dalam program pemuliaan (Hairmansis $e t$ al. 2005). Dimana padi lokal di wilayah Barat-Selatan Aceh merupakan plasma nutfah yang potensial perlu dilestarikan sebagai sumber genetik. Untuk mengatasi semakin berkurangnya sumber gen yang potensial maka perlu dilakukan pelestarian bahan genetik tanaman melalui kegiatan eksplorasi, karakterisasi, rejuvinasi dan dokumentasi (Hanarida et al. 2005).

Pelestarian plasma nutfah disertai dengan identifikasi karakter agronomi. merupakan upaya dalam menyediakan gen-gen yang bermanfaat untuk perkembangan teknologi pertanian berkelanjutan yang digunakan dalam perakitan suatu varietas baru yang bersifat unggul. Karakterisasi terhadap suatu 
tanaman akan mampu memberikan informasi yang deskriptif terhadap sifatsifat penting yang di miliki oleh suatu tanaman. Liu et al (2007) menyatakan bahwa masing-masing varietas memiliki sifat tertentu yang karakteristik dapat digunakan untuk disilangkan antara varietas yang satu dengan varietas lainya.

Untuk menghindari lenyapnya genotipe padi lokal yang ada dan masih banyak dibudidayakan oleh petani, maka perlu dilakukan eksplorasi di berbagai Kabupaten di Wilayah Barat- Selatan Aceh guna mendapatkan informasi.

Padi lokal yang masih banyak dibudidayakan oleh petani terutama di wilayah Barat-Selatan Aceh sangat beragam. Bakhtiar et al (2011) melaporkan bahwa varietas lokal padi Aceh sangat beragam. Namun demikian, potensi padi lokal tersebut sebagai sumber gen belum dievaluasi dan diidentifikasi, disebabkan meluasnya penggunaan varietas unggul nasional. Oleh karena itu diperlukan identifikasi karakter agronomi agar dapat dimanfaatkan dalam program pemulian tanaman (Bhuyan et al. 2007), dan dapat dijadikan langkah awal dalam identifikasi genotipe sebagai tetua untuk pembentukan populasi dasar, serta sebagai dasar untuk pengajuan perlindungan varietas tanaman (Menkumham, 2000).

Berdasarkan uraian diatas dilakukan eksplorasi padi lokal di Wilayah Barat-Selatan Aceh untuk medapatkan informasi keberadaan padi lokal untuk dijadikan sebagai sumber daya genetik dalam perakitan varietas unggul baru. Tujuan penelitian ini adalah untuk mengetahui keberadaan genotipe potensial padi lokal di Wilayah Barat-Selatan Aceh.

\section{METODE}

Eksplorasi genotipe potensial padi lokal dilakukan pada wilayah BaratSelatan Aceh terdiri dari beberapa Kabupaten yaitu Aceh Jaya, Aceh Barat, Nagan Raya, Aceh Barat Daya, Aceh
Selatan dan Simeulue. Kegiatan eksplorasi padi lokal potensial dilakukan dengan cara survei langsung ke lahan/ladang petani yang masih membudidaya padi lokal. Data plasma nutfah padi lokal yang dikoleksi adalah nama lokal, nama lokasi desa, kecamatan, kabupaten. Informasi cara budidaya oleh petani juga dikumpulkan yang meliputi cara tanam, waktu tanam, produksi dan agroekologi setempat.

Pengamatan keragaan fisik tanaman dilakukan dengan mengukur tinggi tanaman, panjang malai, jumlah bulir dan jumlah anakan. Benih padi juga dikoleksi dan disimpan di Laboratorium Pemulian Tanaman Progran Studi Agroteknologi Fakultas Pertanian Universitas Teuku Umar sebagai sumber genetik untuk kegiatan identifikasi karakter agronomi dan morfologi.

\section{HASIL DAN PEMBAHASAN}

Berdasarkan hasil survei tim peneliti di wilayah Barat-Selatan Aceh terdapat beberapa genotipe-gonotipe potensial padi lokal di kabupaten dalam wilayah Barat-Selatan Aceh yang masih dibudidaya oleh petani di pedalaman (Gambar 1).

Hasil eksplorasi keberadaan genotipe potensial padi lokal di wilayah Barat-Selatan Aceh yaitu kabupaten Aceh Jaya : Tinggong, Jantoeng, Sikleng, Ramos, Sijane, Dewi dan Leukat Jeuram kabupaten Aceh Barat : Itam Tangke Lango, Kepala Gidan Kinco, Lekat jerajak Lango, Sirendeh Semantuk Wayla dan Bo Rayek Semantok Wayla. Kabupaten Nagan Raya : Siputeh, Manyam U dan Lekat Tuleng, Kabupaten Aceh Barat Daya : Sigupai. Kabupaten Aceh Selatan : Sitandun, Silian. Kabupaten Simeulue : Sambai dan Pade Sialek (Gambar 1). Hasil eksplorasi, padi lokal tersebut disimpan dan diidentifikasi karakterisasi agronomi untuk dijadikan sebagai sumber daya genetik dalam program pemuliaan tanaman untuk merakit varietas unggul baru. 


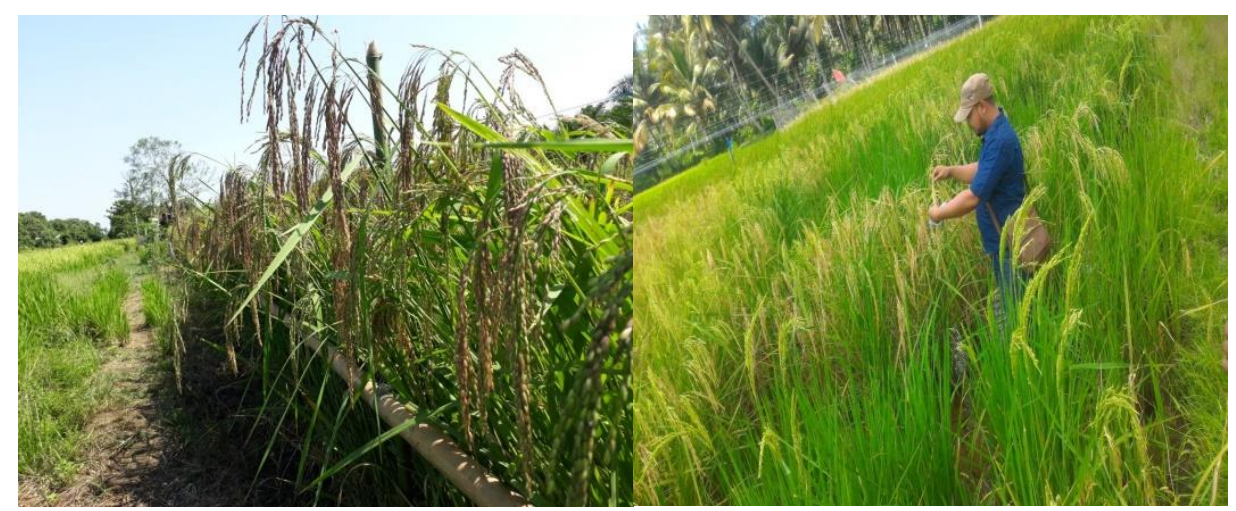

Gambar 1. Eksplorasi padi lokal wilayah Barat-Selatan Aceh

Menurut Permentan Nomor: 67/Permentan/OT.140/12/2006, eksplorasi sumber daya genetik tanaman yang selanjutnya disebut eksplorasi adalah kegiatan pencarian dan pengumpulan, yang kemudian diikuti dengan identifikasi, karakterisasi, dokumentasi, dan evaluasi. Sedangkan koleksi sumber daya genetik tanaman yang selanjutnya disebut koleksi adalah kegiatan pengumpulan yang diikuti dengan penyimpanan dan pemeliharaan sumber daya genetik tanaman hasil eksplorasi, baik dalam bentuk materi maupun informasi sumber daya genetik Tanaman padi.

Padi lokal yang masih banyak dibudidayakan oleh petani terutama di wilayah Barat-Selatan Aceh sangat beragam. Bakhtiar et al (2011) melaporkan bahwa varietas lokal padi Aceh sangat beragam. Namun demikian, potensi padi lokal tersebut sebagai sumber gen belum dievaluasi dan diidentifikasi, disebabkan meluasnya penggunaan varietas unggul nasional. Oleh karena itu diperlukan identifikasi karakter agronomi agar dapat dimanfaatkan dalam program pemulian tanaman (Bhuyan et al. 2007), dan dapat dijadikan langkah awal dalam identifikasi genotipe sebagai tetua untuk pembentukan populasi dasar, serta sebagai dasar untuk pengajuan perlindungan varietas tanaman (Menkumham, 2000).

\section{KESIMPULAN DAN SARAN}

Hasil Eksplorasi padi lokal potensial di wilayah Barat-Selatan Aceh diperoleh 20 aksesi padi yang masih di budidayakan oleh petani dari berbagai kabupaten.

\section{DAFTAR PUSTAKA}

Abdullah B. 2009. Progress of rice through recurrent selection. $J$. Agron. Indonesia 37 (3): 188193.

Bakhtiar, Kesumawati E, Hidayat T, Rahmi M. 2011. Karakteristik plasma nutfah padi lokal Aceh untuk perakitan varietas adaptif pada tanah masam. Agrista 15(3): 79-86.

Bhuyan NN, Basanta K, Borah \& Sarma RN. 2007. Genetic diversity analysis in traditional lowland rice (Oryza sativa L,) of Assam using RAPD and ISSR markers Current Science. 93 (7): 967-972.

Hairmansis A, Aswidinnoor $\mathrm{H}$, Trikoesmanityas, dan Suwarno. 2005. Evaluasi daya pemulih kesuburan padi lokal dari kelompok tropical Japonica. Bul. Agron. (33) (3): 1-6.

Hanarida IS, Hasanah M, Adisoemarto S, Thohari M, Nurhadi A, dan Orbani IN. 2005. Seri mengenal Plasma Nutfah Tanaman Pangan. Komisis Nasional Plasma Nutfah. Bogor.

Hawkes JG, Maxted N, and Ford-Lloyd BV. 2000. The ex situ conservation of plant genetic resources. Kluwer Academic Publishers. London. 250p. 
Irawan, Budi, dan Purbayanti K. 2008. Karakterisasi dan kekerabatan kultivar padi lokal di Desa Rancakalong, Kecamatan Rancakalong, Kabupaten Sumedang. Makalah dipresentasikan pada Seminar Nasional PTTI, 21-23 Oktober 2008.

Liu QL, Xu XH, Ren XL, Fu HW, Wu DX, \& Shu QY. 2007. Generation and characterization of low phytic acid germplasm in rice (Oryza sativa L,). Theor Appl Genet 114:803-814.

Makarim AK, dan Suhartatik E. 2009. Morfologi dan Fisiologi Tanaman Padi. Padi Buku I. Balai Besar Penelitian Tanaman Padi Badan Penelitian dan Pengembangan Pertanian. Menteri Hukum dan Hak Asasi Manusia Republik Indonesia 2000, Undang-Undang Republik Indonesi Nomor 29.

Pandey VR, Singh PK, Verma OP, Pandey $P$ (2012). Inter-relationship and path coefficient estimation in rice under salt stress environment. Int. J. Agric. Res. 7(4):169-184.

Silitonga TS. 2010. The use of biotechnology in the characterization, evaluasi, and utilization of Indonesian rice germplasm. J. Agro Biogen 6 (1): 49-56.

Singh RK, Singh US, and Kush GS. 2000. Aromatic rice. Oxford and IBH Publishing Co. Pvt. Ltd. New Delhi.

Sultan SM and Rao LVS. 2013. Germplasm Collection From Last Remnants of Rice Landrace Genetic Diversity. Int J Conserv Sci 4, 4, oct-dec 2013:467-476. 